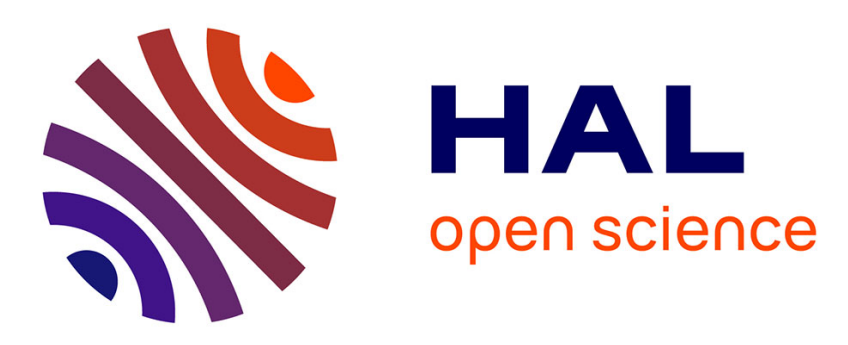

\title{
Thermochemistry of a New Class of Materials Containing Dinitrogen Pairs in an Oxide Matrix
}

Franck Tessier, Laurent Le Gendre, François Cheviré, R. Marchand, A. Navrotsky

\section{- To cite this version:}

Franck Tessier, Laurent Le Gendre, François Cheviré, R. Marchand, A. Navrotsky. Thermochemistry of a New Class of Materials Containing Dinitrogen Pairs in an Oxide Matrix. Chemistry of Materials, 2005, 17 (13), pp.3570-3574. 10.1021/cm050402b . hal-00773004

\section{HAL Id: hal-00773004 https://hal.science/hal-00773004}

Submitted on 16 Feb 2016

HAL is a multi-disciplinary open access archive for the deposit and dissemination of scientific research documents, whether they are published or not. The documents may come from teaching and research institutions in France or abroad, or from public or private research centers.
L'archive ouverte pluridisciplinaire HAL, est destinée au dépôt et à la diffusion de documents scientifiques de niveau recherche, publiés ou non, émanant des établissements d'enseignement et de recherche français ou étrangers, des laboratoires publics ou privés. 


\title{
Thermochemistry of a new class of materials
}

\section{containing dinitrogen pairs in an oxide matrix.}

Franck Tessier, Laurent Le Gendre *, François Cheviré, Roger Marchand and Alexandra Navrotsky ${ }^{+}$

UMR CNRS 6512 "Verres et Céramiques", Institut de Chimie de Rennes, Université de Rennes 1, F35042 Rennes cedex, France

* IUT de St-Brieuc, IETR, UMR CNRS 6164, Université de Rennes 1, F-22004 St-Brieuc,Cedex 01, France

${ }^{+}$Thermochemistry Facility, University of California at Davis, Davis, California 95616-8779, USA

Correspondence should be addressed to Franck.Tessier@univ-rennes1.fr

\begin{abstract}
A series of $\mathrm{N}_{2}$-containing perovskite phases was prepared in the $\mathrm{La}-(\mathrm{Ba})-\mathrm{Ti}-\mathrm{O}$ system in order to study the dinitrogen retention phenomenon from a thermochemical viewpoint. High temperature oxide melt solution calorimetry was undertaken to determine the energetics of the corresponding starting oxynitrides, intermediate phases and oxides. Calorimetric results show that nitrogen is weakly bound within the oxide matrix and most of the enthalpy of oxidation of the intermediate phase is devoted to its structure change between the starting perovskite structure and the formation of a layered-perovskite $\mathrm{La}_{2} \mathrm{Ti}_{2} \mathrm{O}_{7}$ oxide.
\end{abstract}




\section{Introduction}

Nitrides and oxynitrides represent a group of modern ceramic materials of increasing technological importance, with applications as hard materials, protective coatings, electronic and optical materials, refractories, and structural ceramics.

An important aspect of the use of nitride or oxynitride materials is their thermal oxidation behavior. Several investigations of nitride-type compounds have been made with the purpose of clarifying the oxidation mechanism during the transformation into oxide. ${ }^{1-3}$ When heated in an oxygen atmosphere, a nitride or an oxynitride is systematically transformed at relatively high temperature into an oxide, or mixture of oxides, with nitrogen release as molecular dinitrogen. However, an intriguing family of oxynitrides shows a different behavior under similar conditions. As an example, different TGA profiles, under flowing oxygen, of the $\mathrm{RTiO}_{2} \mathrm{~N}$ perovskite series with $\mathrm{R}=\mathrm{La}, \mathrm{Ce}, \mathrm{Pr}, \mathrm{Nd}$ are given in Figure 1 . An unexpected intermediate state, shown in Figure 2, appears between the starting oxynitride and final oxide, with an associated weight change surprisingly higher than that corresponding to the transformation into oxide. This behavior represents a dinitrogen retention phenomenon and the corresponding "intermediate phases" have been isolated and characterized as a new class of dinitrogencontaining inorganic compounds. This behavior has been frequently observed and many intermediate phases have been isolated and structurally characterized as indicated in Table $1 .^{1-10}$ While a significant number of organic dinitrogen-containing compounds, including conventional synthetic organometallic complexes, ${ }^{11}$ as well as biological substances, ${ }^{12}$ are known, the formation of such dinitrogen in inorganic materials is extremely rare. Actually, $M \cdots N \equiv N$ or $M \cdots N \equiv N \cdots M$ units have been only found in the following cases: in pernitrides or diazenides as $\mathrm{BaN}_{2}$ or $\mathrm{SrN}_{2},{ }^{13,14}$ prepared from the elements under high $\mathrm{N}_{2}$ pressure, in products obtained by cocondensation of metallic atoms with $\mathrm{N}_{2}$ at low temperature, ${ }^{15-28}$ in surface layers of titanium dioxide films during their bombardment by $\mathrm{N}_{2}{ }^{+}$ions, ${ }^{29}$ as molecular dinitrogen adsorbed on metallic or oxide substrates at low temperature, ${ }^{30-41}$ and in partially oxidized (oxy)nitride materials, called "intermediate phases", the subject of this paper.

Their decomposition, studied by mass spectroscopy, takes place with a loss of dinitrogen, only, so 
that their general formula can be written $\mathrm{M}^{\mathrm{n}+} \mathrm{O}_{\mathrm{n} / 2}\left(\mathrm{~N}_{2}\right)_{\mathrm{x}}$. Such an intermediate phase composition implies nitrogen atoms at a near zero oxidation state. By comparison to structures from organic chemistry, in particular of dinitrogen organometallic complexes, and also from XPS and Raman analysis, ${ }^{2,3}$ it has been concluded that nitrogen is present as $\mathrm{N}-\mathrm{N}$ pairs interacting with one or several cationic elements.

The basic thermodynamic properties of (oxy)nitride compounds and the relations among energetics, structure and bonding are generally far less well known than for oxides. We have performed a calorimetric study to evaluate the energetics of the specific interaction between $\mathrm{N}_{2}$ entities and the host structure. Intermediate phases have been prepared starting from $\mathrm{LaTiO}_{2} \mathrm{~N}$ and $\mathrm{La}_{0.7} \mathrm{Ba} 0.3 \mathrm{Ti}(\mathrm{O}, \mathrm{N})_{3}$ oxynitrides. High temperature oxidative drop solution calorimetry in a molten oxide solvent has been shown to be a general and convenient method to determine the heat of formation of nitrides and oxynitrides. Studies have already been successfully performed on the energetics of binary and ternary transition metal nitrides, $\mathrm{Si}_{3} \mathrm{~N}_{4}$ and sialon systems, $\mathrm{GaN}$ and nitridophosphate PON and "LiNaPON" glasses. ${ }^{42-46}$

\section{Experimental}

\section{Precursors}

$\mathrm{La}_{2} \mathrm{Ti}_{2} \mathrm{O}_{7}$ precursor was prepared by molten salt synthesis. ${ }^{47} \mathrm{La}_{2} \mathrm{O}_{3}$ and $\mathrm{TiO}_{2}$ were mixed in the appropriate stoichiometric ratio, and a salt consisting of $50 \mathrm{~mol} . \% \mathrm{NaCl} / 50 \mathrm{~mol} . \% \mathrm{KCl}$ was then added, constituting $50 \mathrm{wt} . \%$ of the total reaction mixture. The corresponding mixture was heated at $1273 \mathrm{~K}$ for $15 \mathrm{~h}$. The resulting product was washed using distilled water, then dried at $423 \mathrm{~K}$, and clearly identified as $\mathrm{La}_{2} \mathrm{Ti}_{2} \mathrm{O}_{7}$ (layered perovskite structure) by $\mathrm{X}$-ray diffraction.

In the case of substituted oxynitrides $\mathrm{La}_{1-\mathrm{x}} \mathrm{Ba} \mathrm{a}_{\mathrm{x}} \mathrm{Ti}(\mathrm{O}, \mathrm{N})_{3}$, the oxide precursor corresponds to a single perovskite phase for $\mathrm{x}>0.5$, while a mixture $\mathrm{La}_{2-\mathrm{p}} \mathrm{Ba}_{\mathrm{p}} \mathrm{Ti}_{2} \mathrm{O}_{7-\mathrm{p} / 2}+\mathrm{Ba}_{1-\mathrm{q}} \mathrm{La}_{\mathrm{q}} \mathrm{TiO}_{3+\mathrm{q} / 2}$ results for $0.1<\mathrm{x}<$ 0.5 . The study was carried out with a precursor corresponding to $\mathrm{x}=0.3$.

Nitridation reactions were carried out in alumina boats placed inside an electric furnace through which ammonia gas flowed at $40-50 \mathrm{~L} \mathrm{~h}^{-1}$. The temperature was raised to the $1223-1273 \mathrm{~K}$ range with a heating rate of $10 \mathrm{~K} \mathrm{~min}^{-1}$. After a reaction time of $15 \mathrm{~h}$, the furnace was switched off and the nitrided 
powders were allowed to cool to room temperature under a pure nitrogen atmosphere. Oxynitride perovskites $\mathrm{LaTiO}_{2} \mathrm{~N}$ and $\mathrm{La}_{0.7} \mathrm{Ba}_{0.3} \mathrm{TiO}_{2.3} \mathrm{~N}_{0.7}$ were prepared and oxidized at $873 \mathrm{~K}$ to form intermediate phases listed in Table $1 .^{3}$

\section{Characterizations}

\section{X-ray diffraction.}

XRD powder patterns were recorded using a Philips PW3710 diffractometer operating with $\mathrm{CuK}_{\alpha}$ radiation $(\lambda=1.5418 \AA$ ). X'PERT softwares - Data Collector and Graphics and Identify - were used, respectively, for recording, analysis and phase matching of the patterns. The intermediate phase crystallizes, as previously observed, ${ }^{1-3}$ in the same structure type as its oxynitride precursor with a diffraction profile typical of a poorly crystallized material.

\section{Elemental analysis.}

Nitrogen and oxygen contents were determined with a LECO TC -436 analyzer using the inert gas fusion method. Nitrogen was detected as $\mathrm{N}_{2}$ by thermal conductivity and oxygen as $\mathrm{CO}_{2}$ by infrared detection. The apparatus was calibrated using $\mathrm{N}_{2}$ and $\mathrm{CO}_{2}$ gas (purity $\geq 99.95 \%$ ) as well as $\varepsilon-\mathrm{TaN}$ as a nitrogen standard. ${ }^{48}$

\section{Thermogravimetric analysis (TGA)}

The oxidation behavior of the different oxynitride phases was investigated with a thermobalance Setaram TGDTA 92 in the 298-1673 K temperature range. The samples were tested in static air $(\mathrm{P}=1$ atm) with constant heating rates always lower than $1 \mathrm{~K} \mathrm{~min}^{-1}$. The phases present after oxidation were identified by powder X-ray diffraction. Thermograms are similar to those previously obtained with other systems (Figures 1 and 2). ${ }^{1-10}$ 


\section{X-ray photoelectron (XPS) and Raman spectroscopies.}

XPS measurements were performed on a SSI model 206 spectrometer (Surface Science Instrument) equipped with a monochromatic $\mathrm{Al} \mathrm{K} \alpha \mathrm{X}$-ray source $(1486.6 \mathrm{eV})$. More experimental details are given elsewhere. ${ }^{2,3,49}$ XPS analysis show a single peak N1s close to $402 \mathrm{eV}$ characteristic of $\mathrm{N}_{2}$.

Room temperature Raman spectra were obtained with a Spectra Physics argon ion laser (Model 2000) excitation. The experimental setup was described earlier ${ }^{2}$ and Raman spectroscopy confirms the previous XPS results: a single peak close to $2328 \mathrm{~cm}^{-1}$ reveals that the retained nitrogen exists as $\mathrm{N}_{2}$ entities within a symmetric environment. The Raman peak position compares to that of $2330 \mathrm{~cm}^{-1}$ in $\mathrm{N}_{2}$ gas, $1380 \mathrm{~cm}^{-1}$ in $\mathrm{SrN}$ and $1307 \mathrm{~cm}^{-1}$ in $\mathrm{SrN}_{2}\left(\left(\mathrm{~N}_{2}\right)^{2-}\right.$ pairs $) .{ }^{50}$

\section{Calorimetry}

High temperature oxidative drop solution calorimetry into a $3 \mathrm{Na}_{2} \mathrm{O}-4 \mathrm{MoO}_{3}$ molten solvent was performed in a Calvet type twin calorimeter described in detail by Navrotsky. ${ }^{51,52}$ The solvent was prepared from $\mathrm{Na}_{2} \mathrm{MoO}_{4}, 2 \mathrm{H}_{2} \mathrm{O}$ and $\mathrm{MoO}_{3}$, dehydrated and liquefied at $975 \mathrm{~K}$, and quenched to room temperature by pouring into a graphite dish. The melt does not quench to a glass, so the entire batch was ground to a powder to homogenize it before it was loaded into the calorimetric crucibles. Oxygen gas was used only for bubbling through the solvent (at $\sim 5 \mathrm{~cm}^{3} \mathrm{~min}^{-1}$ ) to stir the melt and oxidize the oxynitride sample once it reached the solvent. When a stable baseline signal was achieved, a sample pellet was dropped from room temperature into liquid $3 \mathrm{Na}_{2} \mathrm{O}-4 \mathrm{MoO}_{3}$ at $975 \mathrm{~K}$ in the calorimeter. When $\mathrm{N}^{3-}$ is present, the calorimetry utilizes a redox reaction between $\mathrm{MoO}_{3}$ in the melt and $\mathrm{N}^{3-}$, which supplies a rapid pathway for elimination of $\mathrm{N}^{3-}$ as $\mathrm{N}_{2}$ gas. The reaction includes the oxidation and the dissolution of the oxynitride, and represents the heat effect measured through oxidative drop solution calorimetry $\left(\Delta \mathrm{H}_{\mathrm{ds}}\right)$. Further details of the experimental procedure are provided in previous papers. ${ }^{53-55}$

\section{Results and discussion}


Drop solution calorimetry has been performed on oxynitride perovskites $\mathrm{LaTiO}_{2} \mathrm{~N}$ and $\mathrm{La}_{0.7} \mathrm{Ba}_{0.3} \mathrm{TiO}_{2.20} \mathrm{~N}_{0.77}$, as well as on intermediate phases $\mathrm{LaTiO}_{3.5} \mathrm{~N}_{\mathrm{x}}(\mathrm{x}=0.54$ and 0.64$)$ and $\mathrm{La}_{0.7} \mathrm{Ba}_{0.3} \mathrm{TiO}_{3.5} \mathrm{~N}_{\mathrm{x}}(\mathrm{x}=0.57,0.59$ and 0.62$)$. Experimental enthalpies of drop solution are gathered in Table 2. Resulting enthalpies of formation and oxidation have been determined from these data (Table 2 and 3) and appropriate thermodynamic cycles detailed in Tables 4 to 10. The enthalpy of formation of $\mathrm{La}_{2} \mathrm{Ti}_{2} \mathrm{O}_{7}$ was determined from the cycle given in Table 6 . The accuracy of the enthalpy of drop solution of $\mathrm{La}_{2} \mathrm{O}_{3}\left(\Delta \mathrm{H}_{1}\right)$ was recently checked with a non hydrated sample and corrected to the value $-225.10 \pm$ $3.16 \mathrm{~kJ} \mathrm{~mol}^{-1} .{ }^{56}$ Using the experimental drop solution enthalpy value $\Delta \mathrm{H}_{5}=98.52 \pm 0.95 \mathrm{~kJ}^{\mathrm{mol}^{-1}}$ determined by Helean et al., ${ }^{57}$ we establish the enthalpy of formation $\Delta \mathrm{H}^{\circ}{ }_{\mathrm{f}}\left(\mathrm{La}_{2} \mathrm{Ti}_{2} \mathrm{O}_{7}\right)$ to $-3890.92 \pm$ $4.67 \mathrm{~kJ} \mathrm{~mol}^{-1}$ and not $-3855.5 \pm 3.5 \mathrm{~kJ} \mathrm{~mol}^{-1}$ as initially reported by these authors.

Heats of drop solution of nitrogen-containing intermediate phases are endothermic and within $20 \mathrm{~kJ}$ $\mathrm{mol}^{-1}$ of those of the nitrogen-free products. Thus, no major oxidation phenomenon, with associated strong exothermic effect, is occuring. The enthalpies of formation of $\mathrm{LaTiO}_{3.5} \mathrm{~N}_{\mathbf{x}}$ phases are close to each other and less exothermic than that of $\mathrm{LaTiO}_{3.5}$ oxide, as expected. The heat of drop solution of intermediate phases does not depend much on nitrogen content, though there is not much variation in nitrogen content. The small difference in enthalpy suggests that nitrogen is weakly bound to the oxide network.

We have devised cycles (Tables 4 and 5) representing the oxidation of the intermediate phases as an approach to determine the energetic contribution of $\mathrm{N}_{2}$ pairs within the oxide matrix. The intermediate phases $\mathrm{La}_{0.7} \mathrm{Ba}_{0.3} \mathrm{TiO}_{3.5} \mathrm{~N}_{\mathrm{x}}$ are not well cystallized but represent perovskite derived structures. They decompose to crystalline $\mathrm{BaTiO}_{3}$ (perovskite) and $\mathrm{La}_{2} \mathrm{Ti}_{2} \mathrm{O}_{7}$ (layered perovskite). We suggest that the observed enthalpy associated with release of $\mathrm{N}_{2}$ gas contains two contributions, that from any oxidation or bonding change of the dinitrogen and, that arising from the transformation of the $\mathrm{LaTiO}_{3.5}$ component from the perovskite to the stable layered structure. However, only 0.7 mole of $\mathrm{LaTiO}_{3.5}$ is formed as compared to one mole for the non barium-substituted $\mathrm{La}-\mathrm{Ti}$ system. Thus, for the La-Ba-Ti system, it 
is necessary to divide the mixed system (La--Ba--Ti) by 0.7 to get the same number of moles of $\mathrm{LaTiO}_{3.5}$. Then, interestingly, we obtain a very similar heat effect to the pure La-Ti system. The measured enthalpies of decomposition, between -19 and $-26 \mathrm{~kJ} \mathrm{~mol}^{-1}$, are relatively constant, suggesting that the phase transition dominates the energetics. Thus, most of the energetics is tied up with the structure change, from a perovskite to a layered-perovskite structure, and not with the $\mathrm{N}_{2}$ bonding. The release of nitrogen may have an effect on the $5-10 \mathrm{~kJ} \mathrm{~mol}^{-1}$ level and the energetics of the phase transition may release $20-25 \mathrm{~kJ} \mathrm{~mol}^{-1}$.

It is also possible to determine the energetics of formation of the oxynitride perovskite $\mathrm{LaTiO}_{2} \mathrm{~N}$ from the cycle in Table 7. Heat contents $\mathrm{H}_{975}-\mathrm{H}_{298}$ of $\mathrm{N}_{2}$ and $\mathrm{O}_{2}$ are respectively $\Delta \mathrm{H}_{7}=20.65$ and $\Delta \mathrm{H}_{8}=21.84 \mathrm{~kJ} \mathrm{~mol}^{-1} .{ }^{58}$ From the enthalpy of drop solution $\Delta \mathrm{H}_{\mathrm{ds}}=-485.16 \pm 4.65 \mathrm{~kJ} \mathrm{~mol}^{-1}$, we calculate the enthalpy of formation $\Delta \mathrm{H}_{\mathrm{f}}^{\circ}\left(\mathrm{LaTiO}_{2} \mathrm{~N}\right)=-1417.10 \pm 5.18 \mathrm{~kJ} \mathrm{~mol}^{-1}$. A similar approach allows us to determine the enthalpy of the barium-containing oxynitride perovskite $\mathrm{La}_{0.7} \mathrm{Ba}_{0.3} \mathrm{TiO}_{2.20} \mathrm{~N}_{0.77}$. From the thermochemical cycle given in Table 8 an enthalpy of formation $\Delta \mathrm{H}_{\mathrm{f}}^{\circ}\left(\mathrm{La}_{0.7} \mathrm{Ba}_{0.3} \mathrm{TiO}_{2.3} \mathrm{~N}_{0.7}\right)$ $=-1506.43 \pm 2.03 \mathrm{~kJ} \mathrm{~mol}^{-1}$ is obtained. Compared to the enthalpy of formation of $\mathrm{LaTiO}_{2} \mathrm{~N}$, this value is more exothermic. Barium has a stabilizing effect through the concept of the well known inductive effect in solid state chemistry, ${ }^{58}$ but the trend is not totally explained because nitrogen contents are different and the differences in the standard enthalpies of $\mathrm{BaO}\left(-548.10 \mathrm{~kJ} \mathrm{~mol}^{-1}\right)$ and $\mathrm{La}_{2} \mathrm{O}_{3}(-1793.7$ $\mathrm{kJ} \mathrm{mol}^{-1}$ ) contribute as major factors.

\section{Acknowledgment.}

The authors are grateful for financial support from the France-Berkeley Fund and from the U.S. Department of Energy (grant DE-FG0397SF14749 ). 


\section{References}

(1) Le Gendre, L.; Thesis n¹907, Université de Rennes, France, 1997.

(2) Le Gendre, L.; Marchand, R.; Laurent, Y. J. Eur. Ceram. Soc. 1997, 17, 1813.

(3) Le Gendre, L.; Marchand, R.; Piriou B. Eur. J. Solid State Inorg. Chem. 1997, 34, 973.

(4) Ohran, E.; Tessier, F.; Marchand, R. Solid State Sci. 2002, 4, 1071.

(5) Clarke, S.J; Michie, C.W.; Rosseinsky, M.J. J. Solid State Chem. 1999, 146, 309.

(6) Van Krevel, J.W.H.; Hintzen, H. T.; Metselaar, R.; Le Gendre, L.; Marchand, R. Solid State Sci. $2001,3,49$.

(7) Wang, X.H.; Lejus,A.-M.; Vivien, D. J. Am. Ceram. Soc. 1990, 73(3), 770.

(8) Veyret, J.-B. ; Van de Voorde, M.; Billy, M. J. Am. Ceram. Soc. 1992, 75, 3289.

(9) Goursat, P.; Billy, M.; Goeuriot, P.; Labbe, J.C.; Villechenoux, J.M.; Roult, G.; Bardolle, J. Mat. Chem. 1981, 6, 81 .

(10) Tobias,G.; Oro-Sole, J.; Beltran-Porter, D.; Fuertes, A. Cryst. Eng. 2002, 5, 479.

(11) Hidai, M.; Mizobe, Y. Chem. Rev. 1995, 95, 1115.

(12) Reis, V.M.; Baldani, J.I.; Divan Baldani, V.L.; Dobereiner, J. Crit. Rev. Plant. Sci. 2000, 19(3), 227.

(13) Auffermann, G.; Prots, Y.; Kniep, R. Angew. Chem. Int. Ed. 2001, 40(3), 547. Prots, Y.;

Auffermann, G.; Tovar, M.; Kniep, R. Angew. Chem. Int. Ed. 2002, 41(13), 2288.

(14) Vajenine, G.V.; Auffermann, G.; Prots, Y.; Schnelle, W.; Kremer, R.K.; Simon, A.; Kniep, R. Inorg. Chem. 2001, 40, 4866.

(15) Ozin, G.A.; Van der Voet, A. Can. J. Chem. 1973, 51, 3332.

(16) Burdett, J.K.; Turner, J.J. J. Chem. Soc., Chem. Commun. 1971, 16, 885.

(17) Ozin, G.A.; Klotzbucher, W. J. Am. Chem. Soc. 1975, 97, 3965.

(18) Huber, E.; Kundig, E.P.; Moskovitz, M.; Ozin, G.A. J. Am. Chem. Soc. 1973, 95, 332.

(19) Crichton, O.; Rest, A.J. J. Chem. Soc., Dalton Trans. 1977, 6, 536.

(20) De Vore, T.C. Inorg. Chem. 1976, 15, 1315.

(21) Huber, H.; Ford, T.A.; Klotzbucher, W.; Ozin, G.A. J. Am. Chem. Soc. 1976, 15, 98, 3176. 
(22) Busby, R.; Klotzbucher, W.; Ozin, G.A. Inorg. Chem. 1977, 16, 822..

(23) Green, D.W.; Hodges, R.V.; Gruen, D.M. Inorg. Chem. 1976, 15, 971.

(24) Burdett, J.K.; Graham, M.A.; Turner, J.J. J. Chem. Soc., Dalton Trans. 1972, 1620.

(25) Rest, A.J. J. Organomet. Chem. 1972, C76, 40.

(26) Moskovits, M.; Ozin, G.A. J. Chem. Phys. 1973, 58, 1251.

(27) Andrews, L.; Citra, A.; Chertihin, G.V. ; Bare, W.D.; Neurock, M. J. Phys. Chem. A 1998, 102, 2561.

(28) Manceron, L.; Alikhani, M.E.; Joly, H.A. Chem. Phys. 1998, 228, 73.

(29) Wolff M., Schultze J.W., Strehblow H. H. Surf. And Interf. Analysis 1991, 17, 726.

(30) Shinn, N.D.; Tsang, K.L. J. Vac. Sci. Technol. 1991, A9(3), 1558.

(31) Fuggle, J.C.; Menzel, D. Vakuum Technik 1977, 27(5), 130.

(32) Johnson, D.W.; Roberts, M.W. Surf. Sci. 1979, 87, L255.

(33) Nilsson, A.; Tillborg, H.; Martensson, N. Phys. Rev. Lett. 1991, 67(8), 1015.

(34) Wakabayashi, F.; Kondo, J.; Wada, A.; Domen, K.; Hirose, C. J. Phys. Chem. 1993, 97, 10761.

(35) Kameoka, S.; Kuroda, M.; Uetsuka, H.; Hito, S.; Kunimori,. K. J. Chem. Soc., Faraday Trans. 1996, 92(9), 1643.

(36) Atzei, D.; De Filipo, D.; Rossi, A. Spectrochim. Acta 1993, 49(A)-12, 1779.

(37) Birchem, T.; Muhler, M. Surf. Sci. 1995, 334, L701.

(38) Wang, H.P; Yates Jr., J.T. J. Phys. Chem. 1984, 88, 852.

(39) Arumainayagam, C.R.; Tripa, C.E.; Xu, J.; Yates Jr., J.T. Surf. Sci. 1996, 360, 121.

(40) Vettraino, M.; Trudeau, M.; Lo, A. Y. H.; Schurko, R. W.; Antonelli, D. J. Am. Chem. Soc. 2002, 124(32), 9567.

(41) Recchia, S.; Dossi, C.; Psaro, R.; Fusi, A.; Ugo, R.; Moretti, G. J. Phys. Chem. B. 2002, 106(51), 13326.

(42) Navrotsky, A. J. Alloys Comp. 2001, 321, 300.

(43) Tessier, F.; Navrotsky, A.; Le Sauze, A.; Marchand, R. Chem. Mater. 2000, 12, 148.

(44) Tessier, F.; Navrotsky, A.; Niewa, R.; Leineweber, A.; Jacobs, H.; Kikkawa, S.; Takahashi, M.; Kanamaru, F.; DiSalvo, F.J. Solid State Sci. 2000, 2, 457. 
(45) Ranade, M.R.; Tessier, F.; Navrotsky, A.; Leppert, V.J.; Risbud, S.H.; DiSalvo, F.J.; Balkas, C.M. J. Phys. Chem. B 2000, 104(17), 4060.

(46) Ranade, M.R.; Tessier, F.; Navrotsky, A.; Marchand, R. J. Mater. Res. 2001, 16(10), 2824.

(47) Fuierer, P.A.; Newnham, R.E. J. Am. Ceram. Soc. 1991, 74, 2876.

(48) Dopita, M.; Wollein, B.; Rafaja, D.; Gruner, W.; Lengauer, W. Defect and Diffusion Forum, diffusion in materials DIMAT-2000 2001, 194-199, 1613.

(49) Wiame, H.; Centeno, M.-A.; Picard, S.; Bastians, P.; Grange, P. J. Eur. Ceram.Society 1998, 18(9), 1293.

(50) Auffermann, G.; Prots, Y.; Kniep, R.; Parker, S.F.; Bennington, S.M.; ChemPhysChem. 2002, 3, 815.

(51) Navrotsky, A. Phys. Chem. Miner. 1977, 2, 89.

(52) Navrotsky, A. Phys. Chem. Miner. 1997, 24, 222.

(53) McHale, J.M.; Kowach, G.R.; Navrotsky, A.; DiSalvo, F.J. Chem. Eur. J. 1996, 2(12), 1514.

(54) McHale, J.M.; Navrotsky, A.; Kowach, G.R.; Balbarin, V.E.; DiSalvo, F.J. Chem. Mater. 1997, 9, 1538.

(55) McHale, J.M.; Navrotsky, A.; DiSalvo, F.J. Chem. Mater. 1999, 11(4), 1148.

(56) Cheng, J.; Navrotsky, A. J. Mater. Res. 2003, 18(10), 2501.

(57) Helean, K.B.; Ushakov, S.V.; Brown, C.E.; Navrotsky, A.; Liang, J.; Ewing, R.C.; Farmer, J.M.; Boatner, L.A. J. Solid State Chem. 2004, 177(6), 1858.

(58) Chase, M.W.; et al. JANAF Thermochemical Tables, $3^{\text {rd }}$ ed.; Journal of Physical and Chemical Reference Data; American Chemical Society: Washington, DC, (1985, Vol.14, Suppl. n¹).

(59) Robie, R.A.; Hemingway, B.S. Thermodynamic Properties of Minerals and related Substances at $295.15 \mathrm{~K}$ and $1 \mathrm{Bar}\left(10^{5} \mathrm{~Pa}\right)$ Pressure and at Higher Temperatures (US Geological Survey Bulletin 2131, Washington DC, 1995).

(60) Ranade, M.R.; Navrotsky, A.; Zhang, H.Z.; Banfield, J.F.; Elder, S.H.; Zaban, A.; Borse, P.H.; Kulkarni, S.K.; Doran, G.S.; Whitfield, H.J. Proc. Nat. Acad. Sci. 2002, 99, suppl 2, 6476.

(61) Barin, I. Thermochemical Data of Pure Substances VCH- New York, 1989. 


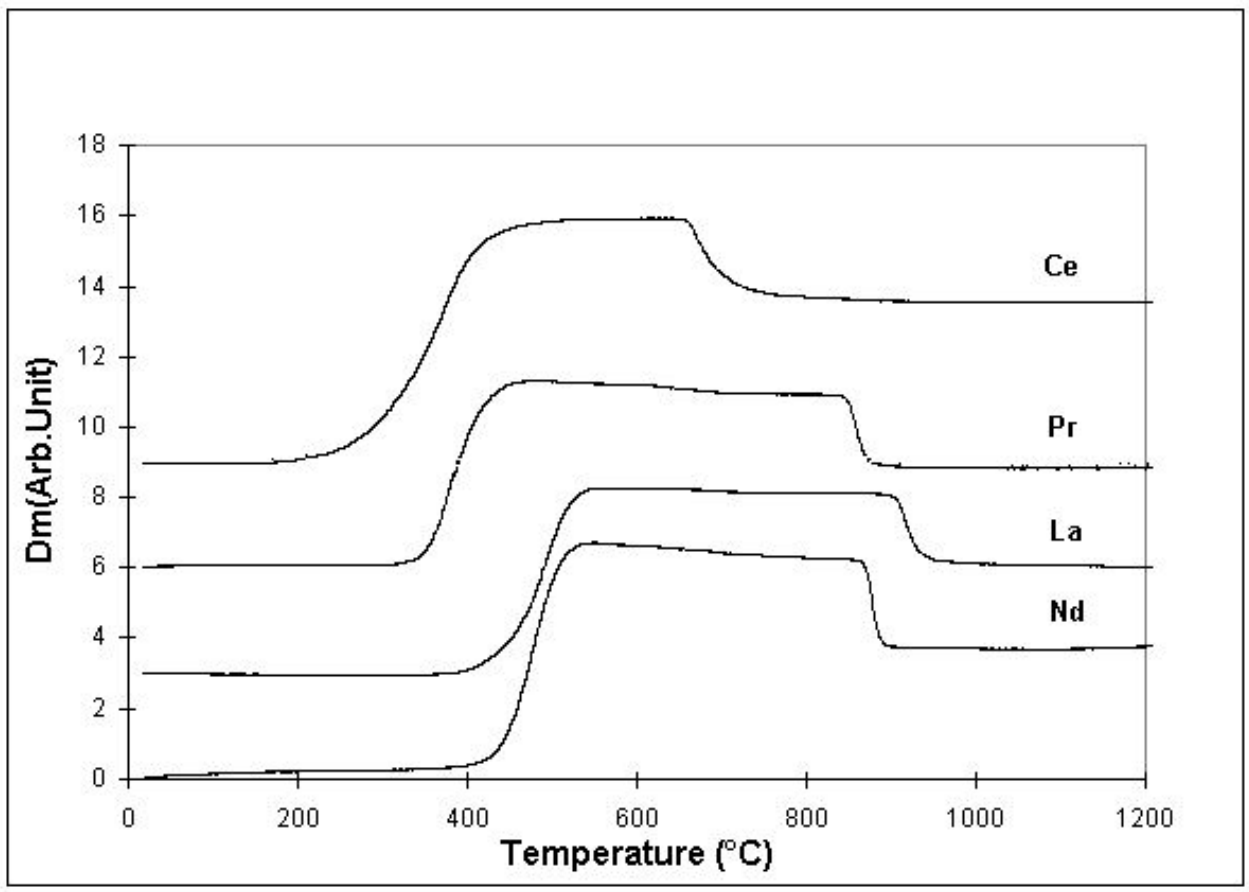

Figure 1. TGA under $\mathrm{O}_{2}$ of $\mathrm{RTiO}_{2} \mathrm{~N}$ phases $(\mathrm{R}=\mathrm{Ce}, \mathrm{Pr}$, La and $\mathrm{Nd})\left(1^{\circ} \mathrm{C} \cdot \mathrm{min}-1\right)$

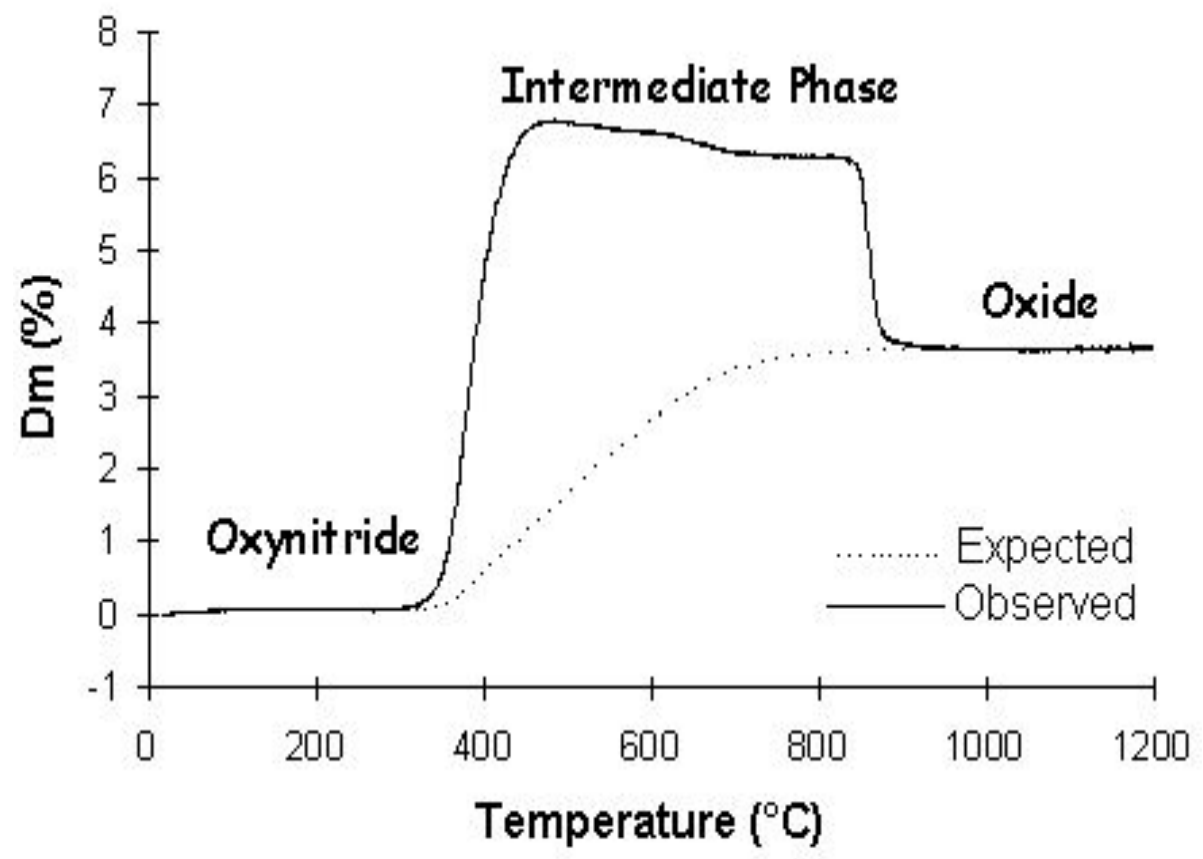

Figure 2. TGA analysis of an oxynitride manifesting the "intermediate phase" phenomenon. 


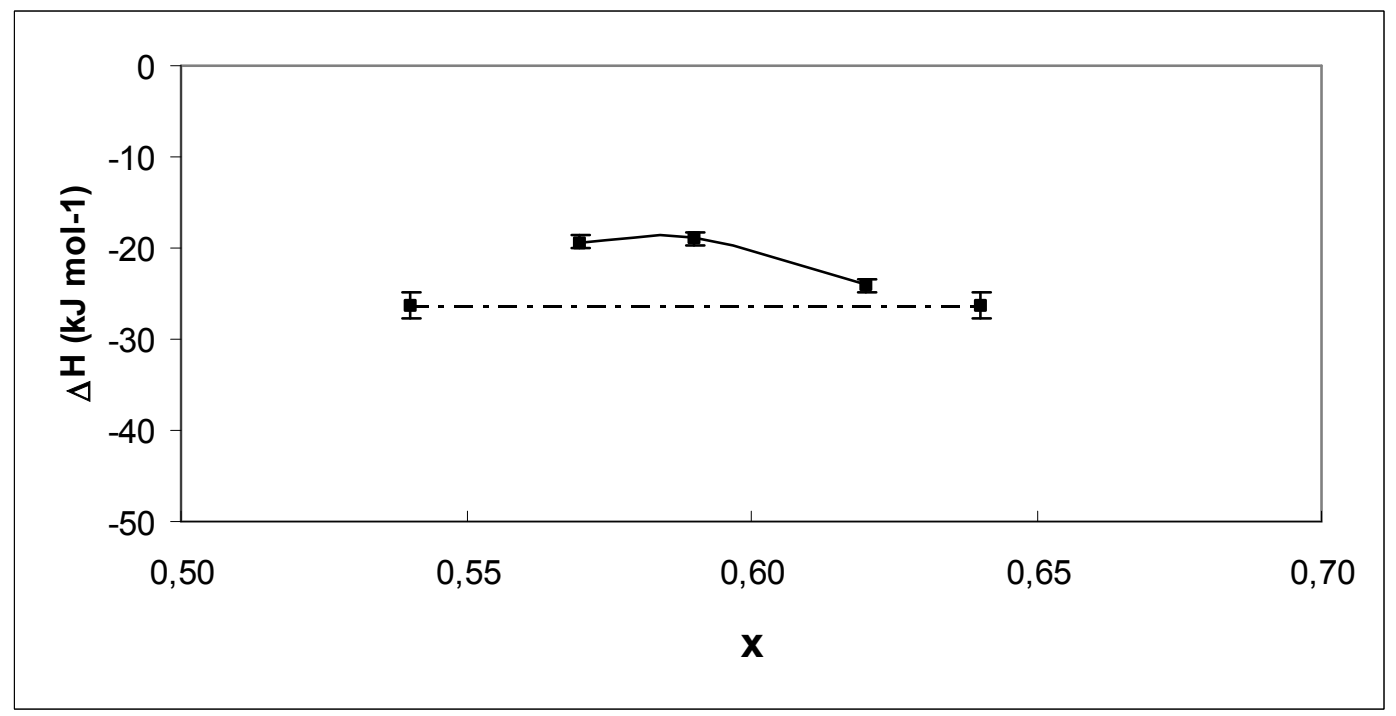

Figure 3. Enthalpies of oxidation (per mole of lanthanum) versus nitrogen content within $\mathrm{LaTiO}_{3.5} \mathrm{~N}_{\mathrm{x}}$ (dashed line) and $\mathrm{La}_{0.7} \mathrm{Ba}_{0.3} \mathrm{TiO}_{3.35} \mathrm{~N}_{\mathrm{x}}$ (solid curve) intermediate phases. 
Table 1. Evidence of intermediate phases in several structure types

\begin{tabular}{|c|c|c|c|}
\hline Oxynitride & Structural type & $\begin{array}{l}\text { Intermediate phase } \\
\quad \text { formula }\end{array}$ & Ref. \\
\hline $\mathrm{BaTaO}_{2} \mathrm{~N}$ & perovskite & $\mathrm{BaTaO}_{3.5}\left(\mathrm{~N}_{2}\right)_{0.15}$ & 2 \\
\hline $\mathrm{La}_{0.91} \mathrm{~W}_{0.91} \square_{0.18} \mathrm{O}_{1.37} \mathrm{~N}_{1.63}$ & perovskite & $\mathrm{LaWO}_{4.5}\left(\mathrm{~N}_{2}\right)_{0.23}$ & 2 \\
\hline $\mathrm{LaTiO}_{2} \mathrm{~N}$ & perovskite & $\mathrm{LaTiO}_{3.5}\left(\mathrm{~N}_{2}\right)_{0.32}$ & 2 \\
\hline $\mathrm{Al}_{2.85} \square 0.15 \mathrm{O}_{3.45} \mathrm{~N}_{0.55}$ & spinelle & $\mathrm{Al}_{2} \mathrm{O}_{3}\left(\mathrm{~N}_{2}\right)_{0.095}$ & 2,9 \\
\hline $\mathrm{Y}_{2.67} \mathrm{~W}_{1.33}\left(\mathrm{O}_{3.79} \mathrm{~N}_{2.80 \square 1.41}\right)$ & fluorite & $\mathrm{Y}_{2} \mathrm{WO}_{6}\left(\mathrm{~N}_{2}\right)_{0.20}$ & 2 \\
\hline $\mathrm{Cr}_{0.77 \square 0.23} \mathrm{O}_{0.69} \mathrm{~N}_{0.31}$ & $\mathrm{NaCl}$ & $\mathrm{Cr}_{2} \mathrm{O}_{3}\left(\mathrm{~N}_{2}\right)_{0.15}$ & 2 \\
\hline $\mathrm{Ti}_{0.67 \square}{ }_{0.33} \mathrm{O}_{0.42} \mathrm{~N}_{0.58}$ & $\mathrm{NaCl}$ & $\mathrm{TiO}_{2}\left(\mathrm{~N}_{2}\right)_{0.06}$ & 2 \\
\hline $\mathrm{Nb}_{0.54 \square 0.46} \mathrm{O}_{0.40} \mathrm{~N}_{0.60}$ & $\mathrm{NaCl}$ & $\mathrm{Nb}_{2} \mathrm{O}_{5}\left(\mathrm{~N}_{2}\right)_{0.43}$ & 2 \\
\hline $\mathrm{TaON}$ & baddeleyite & $\mathrm{TaO}_{2}\left(\mathrm{~N}_{2}\right)_{0.10}$ & 4 \\
\hline $\mathrm{Zr}_{2} \mathrm{~N}_{2} \mathrm{O}$ & bixbyite & $\mathrm{ZrO}_{2}\left(\mathrm{~N}_{2}\right)_{0.028}$ & 5 \\
\hline $\mathrm{Y}_{4} \mathrm{Si}_{2} \mathrm{O}_{7} \mathrm{~N}_{2}$ & cuspidine & $\mathrm{Y}_{4} \mathrm{Si}_{2} \mathrm{O}_{10}\left(\mathrm{~N}_{2}\right)_{0.75}$ & 6 \\
\hline $\mathrm{LaAl}_{12} \mathrm{O}_{18} \mathrm{~N}$ & magnetoplumbite & $\mathrm{LnAl}_{12} \mathrm{O}_{19.5}\left(\mathrm{~N}_{2}\right)_{0.17}$ & 7 \\
\hline $\mathrm{Y}_{5}\left(\mathrm{SiO}_{4}\right)_{3} \mathrm{~N}$ & Apatite & $\mathrm{Y}_{10} \mathrm{Si}_{7} \mathrm{O}_{29}\left(\mathrm{~N}_{2}\right)_{0.335}$ & 8 \\
\hline $\mathrm{Sr}_{2} \mathrm{NbO}_{2.8} \mathrm{~N}$ & $\mathrm{~K}_{2} \mathrm{NiF}_{4}$ & $\mathrm{Sr}_{2} \mathrm{NbO}_{4.5}\left(\mathrm{~N}_{2}\right)_{0.20}$ & 10 \\
\hline $\mathrm{La}_{0.9} \mathrm{Ba}_{0.1} \mathrm{TiO}_{2.1} \mathrm{~N}_{0.9}$ & perovskite & $\mathrm{La}_{0.9} \mathrm{Ba}_{0.1} \mathrm{TiO}_{3.45}\left(\mathrm{~N}_{2}\right)_{0.31}$ & \\
\hline $\mathrm{La}_{0.7} \mathrm{Ba}_{0.3} \mathrm{TiO}_{2.3} \mathrm{~N}_{0.7}$ & & $\mathrm{La}_{0.7} \mathrm{Ba}_{0.3} \mathrm{TiO}_{3.35}\left(\mathrm{~N}_{2}\right)_{0.26}$ & \\
\hline $\mathrm{La}_{0.5} \mathrm{Ba}_{0.5} \mathrm{TiO}_{2.5} \mathrm{~N}_{0.5}$ & & $\mathrm{La}_{0.5} \mathrm{Ba}_{0.5} \mathrm{TiO}_{3.25}\left(\mathrm{~N}_{2}\right)_{0.23}$ & 1 \\
\hline $\mathrm{CeTiO}_{2} \mathrm{~N}$ & & $\mathrm{CeTiO}_{4}\left(\mathrm{~N}_{2}\right)_{0.24}$ & \\
\hline $\mathrm{PrTiO}_{2} \mathrm{~N}$ & & $\operatorname{PrTiO}_{3.5}\left(\mathrm{~N}_{2}\right)_{0.25}$ & \\
\hline $\mathrm{NdTiO}_{2} \mathrm{~N}$ & & $\mathrm{NdTiO}_{3.5}\left(\mathrm{~N}_{2}\right)_{0.26}$ & \\
\hline
\end{tabular}

${ }^{1}$ composition obtained with the highest nitrogen content 
Table 2. Enthalpies of drop solution, decomposition and formation from the elements at $298 \mathrm{~K}$ (kJ mol1) determined in this study.

\begin{tabular}{lccc}
\hline & $\Delta \mathrm{H}$ drop solution & $\begin{array}{c}\Delta \mathrm{H} \text { decomposition } \\
\text { (per mole of La) }\end{array}$ & \multicolumn{1}{c}{$\Delta \mathrm{H}^{\circ}$ formation } \\
\hline $\mathrm{LaTiO}_{3.5}$ & $49.26 \pm 0.47$ & - & $-1944.41 \pm 2.41$ \\
\hline $\mathrm{LaTiO}_{2} \mathrm{~N}$ & $-485.16 \pm 4.65$ & - & $-1417.10 \pm 5.18$ \\
$\mathrm{La}_{0.7} \mathrm{Ba}_{0.3} \mathrm{TiO}_{2.3} \mathrm{~N}_{0.7}$ & $-311.53 \pm 1.14$ & - & $-1506.43 \pm 2.03$ \\
\hline $\mathrm{LaTiO}_{3.5} \mathrm{~N}_{0.64}$ & $29.68 \pm 1.41$ & $-26.19 \pm 1.43$ & $-1919.27 \pm 2.69$ \\
$\mathrm{LaTiO}_{3.5} \mathrm{~N}_{0.54}$ & $28.67 \pm 1.39$ & $-26.17 \pm 1.41$ & $-1919.29 \pm 2.68$ \\
$\mathrm{La}_{0.7} \mathrm{Ba}_{0.3} \mathrm{TiO}_{3.35} \mathrm{~N}_{0.62}$ & $35.56 \pm 0.55$ & $-24.12 \pm 1.04$ & $-1842.88 \pm 1.77$ \\
$\mathrm{La}_{0.7} \mathrm{Ba}_{0.3} \mathrm{TiO}_{3.35} \mathrm{~N}_{0.59}$ & $38.85 \pm 0.53$ & $-18.98 \pm 1.01$ & $-1846.48 \pm 1.76$ \\
$\mathrm{La}_{0.7} \mathrm{Ba}_{0.3} \mathrm{TiO}_{3.35} \mathrm{~N}_{0.57}$ & $38.39 \pm 0.49$ & $-19.34 \pm 0.97$ & $-1846.22 \pm 1.75$ \\
\hline
\end{tabular}
uncertainty is two standard deviations of the mean.

Table 3. Data used in thermodynamic cycles to determine the enthalpy of formation from drop solution calorimetry. All values are in $\mathrm{kJ} \mathrm{mol}^{-1}$.

\begin{tabular}{lc|cc}
\hline & $\Delta \mathrm{H}$ drop solution & $\Delta \mathrm{H}^{\circ}$ formation & Reference \\
\hline $\mathrm{La}_{2} \mathrm{O}_{3}$ & $\Delta \mathrm{H}_{1}=-225.10 \pm 3.16$ & $\Delta \mathrm{H}_{2}=-1793.7 \pm 1.6$ & {$[59]$} \\
$\mathrm{TiO}_{2}$ & $\Delta \mathrm{H}_{3}=57.95 \pm 0.71$ & $\Delta \mathrm{H}_{4}=-944.75 \pm 1.26$ & {$[60]$} \\
$\mathrm{La}_{2} \mathrm{Ti}_{2} \mathrm{O}_{7}$ & $\Delta \mathrm{H}_{5}=98.52 \pm 0.95$ & $\Delta \mathrm{H}_{6}=-3890.92 \pm 4.67$ & this work \\
$\mathrm{BaTiO}_{3}$ & $\Delta \mathrm{H}_{9}=38.53 \pm 0.63$ & $\Delta \mathrm{H}_{10}=-1659.797$ & {$[61]$} \\
\hline
\end{tabular}
uncertainty is two standard deviations of the mean. 
Table 4. Thermochemical cycle for calculation of the enthalpy of decomposition of $\mathrm{LaTiO}_{3.5} \mathrm{~N}_{\mathrm{x}}$

\begin{tabular}{lc}
\hline \multicolumn{1}{c}{ Reaction } & $\Delta \mathrm{H}$ \\
\hline $\mathrm{LaTiO}_{3.5} \mathrm{~N}_{\mathbf{x}}(\mathrm{s}, 298) \rightarrow \mathrm{LaTiO}_{3.5}(\mathrm{~s}, 298)+\mathbf{x} / 2 \mathrm{~N}_{2}(\mathrm{~g}, 298)$ & $\Delta \mathrm{H}$ \\
$\mathrm{LaTiO}_{3.5} \mathrm{~N}_{\mathbf{x}}(\mathrm{s}, 298) \rightarrow \mathrm{LaTiO}_{3.5}(\mathrm{soln}, 975)+\mathbf{x} / 2 \mathrm{~N}_{2}(\mathrm{~g}, 975)$ & $\Delta \mathrm{H}_{\mathrm{ds}}$ \\
$\mathrm{LaTiO}_{3.5}(\mathrm{~s}, 298) \rightarrow \mathrm{LaTiO}_{3.5}(\operatorname{soln}, 975)$ & $1 / 2 \Delta \mathrm{H}_{5}$ \\
$\mathrm{~N}_{2}(\mathrm{~g}, 298) \rightarrow \mathrm{N}_{2}(\mathrm{~g}, 975)$ & $\Delta \mathrm{H}_{7}$ \\
& \\
$\Delta \mathrm{H}=\Delta \mathrm{H}_{\mathrm{ds}}-1 / 2 \Delta \mathrm{H}_{5}-\mathbf{x} / 2 \Delta \mathrm{H}_{7}$ & \\
\hline
\end{tabular}

Table 5. Thermochemical cycle for calculation of the enthalpy of decomposition of $\mathrm{La}_{0.7} \mathrm{Ba}_{0.3} \mathrm{TiO}_{3.35} \mathrm{~N}_{\mathbf{x}}$.

\begin{tabular}{lc}
\hline \multicolumn{1}{c}{ Reaction } & $\Delta \mathrm{H}$ \\
\hline $\begin{array}{l}\mathrm{La}_{0.7} \mathrm{Ba}_{0.3} \mathrm{TiO}_{3.35} \mathrm{~N}_{\mathbf{x}}(\mathrm{s}, 298) \rightarrow 0.7 \mathrm{LaTiO}_{3.5}(\mathrm{~s}, 298)+0.3 \mathrm{BaTiO}_{3}(\mathrm{~s}, 298)+\mathbf{x} / 2 \mathrm{~N}_{2} \\
\mathrm{~g}, 298)\end{array}$ & $\Delta \mathrm{H}$ \\
$\mathrm{La}_{0.7} \mathrm{Ba}_{0.3} \mathrm{TiO}_{3.35} \mathrm{~N}_{\mathbf{x}}(\mathrm{s}, 298) \rightarrow \mathrm{LaTiO}_{3.5}(\operatorname{soln}, 975)+0.3 \mathrm{BaTiO}_{3}(\mathrm{~s}, 975)+\mathbf{x} / 2 \mathrm{~N}_{2}$ & $\Delta \mathrm{H}_{\mathrm{ds}}$ \\
$(\mathrm{g}, 975)$ & $1 / 2 \Delta \mathrm{H}_{5}$ \\
$\mathrm{LaTiO}_{3.5}(\mathrm{~s}, 298) \rightarrow \mathrm{LaTiO}_{3.5}(\operatorname{soln}, 975)$ & $\Delta \mathrm{H}_{9}$ \\
$\mathrm{BaTiO}_{3}(\mathrm{~s}, 298) \rightarrow \mathrm{BaTiO}_{3}(\operatorname{soln}, 975)$ & $\Delta \mathrm{H}_{7}$ \\
$\mathrm{~N}_{2}(\mathrm{~g}, 298) \rightarrow \mathrm{N}_{2}(\mathrm{~g}, 975)$ & \\
$\Delta \mathrm{H}=\Delta \mathrm{H}_{\mathrm{ds}}-0.35 \Delta \mathrm{H}_{5}-\mathbf{x} / 2 \Delta \mathrm{H}_{7}-0.3 \mathbf{x} \Delta \mathrm{H}_{9}$ & \\
\hline
\end{tabular}


Table 6. Thermochemical cycle for calculation of the enthalpy of formation of $\mathrm{La}_{2} \mathrm{Ti}_{2} \mathrm{O}_{7}$.

\section{Reaction}

$\Delta \mathrm{H}$

$\mathrm{La}_{2} \mathrm{O}_{3}(\mathrm{~s}, 298) \rightarrow \mathrm{La}_{2} \mathrm{O}_{3}($ soln, 975)

$\Delta \mathrm{H}_{1}$

$2 \mathrm{La}(\mathrm{s}, 298)+3 / 2 \mathrm{O}_{2}(\mathrm{~g}, 298) \rightarrow \mathrm{La}_{2} \mathrm{O}_{3}(\mathrm{~s}, 298)$

$\Delta \mathrm{H}_{2}$

$\mathrm{TiO}_{2}(\mathrm{~s}, 298) \rightarrow \mathrm{TiO}_{2}$ (soln, 975)

$\Delta \mathrm{H}_{3}$

$\mathrm{Ti}(\mathrm{s}, 298)+\mathrm{O}_{2}(\mathrm{~g}, 298) \rightarrow \mathrm{TiO}_{2}(\mathrm{~s}, 298)$

$\Delta \mathrm{H}_{4}$

$\mathrm{La}_{2} \mathrm{Ti}_{2} \mathrm{O}_{7}(\mathrm{~s}, 298) \rightarrow \mathrm{La}_{2} \mathrm{O}_{3}\left(\right.$ soln, 975) $+2 \mathrm{TiO}_{2}($ soln, 975)

$\Delta \mathrm{H}_{5}$

$2 \mathrm{La}(\mathrm{s}, 298)+2 \mathrm{Ti}(\mathrm{s}, 298)+7 / 2 \mathrm{O}_{2}(\mathrm{~g}, 298) \rightarrow \mathrm{La}_{2} \mathrm{Ti}_{2} \mathrm{O}_{7}(\mathrm{~s}, 298)$

$\Delta \mathrm{H}_{6}$

$\Delta \mathrm{H}^{\circ}{ }_{\mathrm{f}}\left(\mathrm{La}_{2} \mathrm{Ti}_{2} \mathrm{O}_{7}\right)=\Delta \mathrm{H}_{6}=-\Delta \mathrm{H}_{5}+\Delta \mathrm{H}_{1}+\Delta \mathrm{H}_{2}+2\left(\Delta \mathrm{H}_{3}+\Delta \mathrm{H}_{4}\right)$

Table 7. Thermochemical cycle for calculation of the enthalpy of formation of $\mathrm{LaTiO}_{2} \mathrm{~N}$.

\begin{tabular}{|c|c|}
\hline Reaction & $\Delta \mathrm{H}$ \\
\hline $\mathrm{La}_{2} \mathrm{O}_{3}(\mathrm{~s}, 298) \rightarrow \mathrm{La}_{2} \mathrm{O}_{3}(\operatorname{soln}, 975)$ & $\Delta \mathrm{H}_{1}$ \\
\hline $2 \mathrm{La}(\mathrm{s}, 298)+3 / 2 \mathrm{O}_{2}(\mathrm{~g}, 298) \rightarrow \mathrm{La}_{2} \mathrm{O}_{3}(\mathrm{~s}, 298)$ & $\Delta \mathrm{H}_{2}$ \\
\hline $\mathrm{TiO}_{2}(\mathrm{~s}, 298) \rightarrow \mathrm{TiO}_{2}(\operatorname{soln}, 975)$ & $\Delta \mathrm{H}_{3}$ \\
\hline $\mathrm{Ti}(\mathrm{s}, 298)+\mathrm{O}_{2}(\mathrm{~g}, 298) \rightarrow \mathrm{TiO}_{2}(\mathrm{~s}, 298)$ & $\Delta \mathrm{H}_{4}$ \\
\hline $\begin{array}{l}\mathrm{LaTiO}_{2} \mathrm{~N}(\mathrm{~s}, 298)+3 / 4 \mathrm{O}_{2}(\mathrm{~g}, 975) \rightarrow 1 / 2 \mathrm{La}_{2} \mathrm{O}_{3}(\operatorname{soln}, 975)+\mathrm{TiO}_{2}(\operatorname{soln}, 975)+1 / 2 \mathrm{~N}_{2}(\mathrm{~g}, \\
975)\end{array}$ & $\Delta \mathrm{H}_{\mathrm{ds}}$ \\
\hline $\mathrm{La}(\mathrm{s}, 298)+\mathrm{Ti}(\mathrm{s}, 298)+\mathrm{O}_{2}(\mathrm{~g}, 298)+1 / 2 \mathrm{~N}_{2}(\mathrm{~g}, 298) \rightarrow \mathrm{LaTiO}_{2} \mathrm{~N}(\mathrm{~s}, 298)$ & $\Delta \mathrm{H}_{\mathrm{f}}^{\circ}$ \\
\hline $\mathrm{N}_{2}(\mathrm{~g}, 298) \rightarrow \mathrm{N}_{2}(\mathrm{~g}, 975)$ & $\Delta \mathrm{H}_{7}$ \\
\hline $\mathrm{O}_{2}(\mathrm{~g}, 298) \rightarrow \mathrm{O}_{2}(\mathrm{~g}, 975)$ & $\Delta \mathrm{H}_{8}$ \\
\hline$\Delta \mathrm{H}^{\circ}{ }_{\mathrm{f}}\left(\mathrm{LaTiO}_{2} \mathrm{~N}\right)=\Delta \mathrm{H}_{\mathrm{f}}^{\circ}=-\Delta \mathrm{H}_{\mathrm{ds}}+1 / 2\left(\Delta \mathrm{H}_{1}+\Delta \mathrm{H}_{2}\right)+\Delta \mathrm{H}_{3}+\Delta \mathrm{H}_{4}+1 / 2 \Delta \mathrm{H}_{7}-3 / 4 \Delta \mathrm{H}_{8}$ & \\
\hline
\end{tabular}


Table 8. Thermochemical cycle for calculation of the enthalpy of formation of $\mathrm{La}_{0.7} \mathrm{Ba}_{0.3} \mathrm{TiO}_{2.3} \mathrm{~N}_{0.7}$.

\begin{tabular}{|c|c|}
\hline Reaction & $\Delta \mathrm{H}$ \\
\hline $\mathrm{La}_{2} \mathrm{Ti}_{2} \mathrm{O}_{7}(\mathrm{~s}, 298) \rightarrow \mathrm{La}_{2} \mathrm{Ti}_{2} \mathrm{O}_{7}(\operatorname{soln}, 975)$ & $\Delta \mathrm{H}_{5}$ \\
\hline $2 \mathrm{La}(\mathrm{s}, 298)+2 \mathrm{Ti}(\mathrm{s}, 298)+7 / 2 \mathrm{O}_{2}(\mathrm{~g}, 298) \rightarrow \mathrm{La}_{2} \mathrm{Ti}_{2} \mathrm{O}_{7}(\mathrm{~s}, 298)$ & $\Delta \mathrm{H}_{6}$ \\
\hline $\mathrm{N}_{2}(\mathrm{~g}, 298) \rightarrow \mathrm{N}_{2}(\mathrm{~g}, 975)$ & $\Delta \mathrm{H}_{7}$ \\
\hline $\mathrm{O}_{2}(\mathrm{~g}, 298) \rightarrow \mathrm{O}_{2}(\mathrm{~g}, 975)$ & $\Delta \mathrm{H}_{8}$ \\
\hline $\mathrm{BaTiO}_{3}(\mathrm{~s}, 298) \rightarrow \mathrm{BaTiO}_{3}($ soln, 975) & $\Delta \mathrm{H}_{9}$ \\
\hline $\mathrm{Ba}(\mathrm{s}, 298)+\mathrm{Ti}(\mathrm{s}, 298)+3 / 2 \quad \mathrm{O}_{2}(\mathrm{~g}, 298) \rightarrow \mathrm{BaTiO}_{3}(\mathrm{~s}, 298)$ & $\Delta \mathrm{H}_{10}$ \\
\hline $\begin{array}{l}\mathrm{La}_{0.7} \mathrm{Ba}_{0.3} \mathrm{TiO}_{2.3} \mathrm{~N}_{0.7}(\mathrm{~s}, 298)+0.525 \mathrm{O}_{2}(\mathrm{~g}, 975) \rightarrow 0.35 \mathrm{La}_{2} \mathrm{Ti}_{2} \mathrm{O}_{7}(\operatorname{soln}, 975)+0.3 \\
\mathrm{BaTiO}_{3}\left(\text { soln, 975) }+0.35 \mathrm{~N}_{2}(\mathrm{~g}, 975)\right.\end{array}$ & $\Delta \mathrm{H}_{\mathrm{ds}}$ \\
\hline $\begin{array}{l}0.7 \mathrm{La}(\mathrm{s}, 298)+0.3 \mathrm{Ba}(\mathrm{s}, 298)+1.15 \mathrm{O}_{2}(\mathrm{~g}, 298)+0.35 \mathrm{~N}_{2}(\mathrm{~g}, 298) \rightarrow \\
\mathrm{La}_{0.7} \mathrm{Ba}_{0.3} \mathrm{TiO}_{2.3} \mathrm{~N}_{0.7}(\mathrm{~s}, 298)\end{array}$ & $\Delta \mathrm{H}_{\mathrm{f}}^{\circ}$ \\
\hline $\begin{array}{l}\Delta \mathrm{H}_{\mathrm{f}}^{\circ}\left(\mathrm{La}_{0.7} \mathrm{Ba}_{0.3} \mathrm{TiO}_{2.3} \mathrm{~N}_{0.7}\right)=\Delta \mathrm{H}_{\mathrm{f}}^{\circ}=-\Delta \mathrm{H}_{\mathrm{ds}}+0.35\left(\Delta \mathrm{H}_{5}+\Delta \mathrm{H}_{6}\right)+0.3\left(\Delta \mathrm{H}_{9}+\Delta \mathrm{H}_{10}\right) \\
+0.35 \Delta \mathrm{H}_{7}-0.525 \Delta \mathrm{H}_{8}\end{array}$ & \\
\hline
\end{tabular}

Table 9. Thermochemical cycle for calculation of the enthalpy of formation of $\mathrm{LaTiO}_{3.5} \mathrm{~N}_{\mathbf{x}}$

\begin{tabular}{|c|c|}
\hline Reaction & $\Delta \mathrm{H}$ \\
\hline $\mathrm{La}_{2} \mathrm{O}_{3}(\mathrm{~s}, 298) \rightarrow \mathrm{La}_{2} \mathrm{O}_{3}($ soln, 975) & $\Delta \mathrm{H}_{1}$ \\
\hline $2 \mathrm{La}(\mathrm{s}, 298)+3 / 2 \mathrm{O}_{2}(\mathrm{~g}, 298) \rightarrow \mathrm{La}_{2} \mathrm{O}_{3}(\mathrm{~s}, 298)$ & $\Delta \mathrm{H}_{2}$ \\
\hline $\mathrm{TiO}_{2}(\mathrm{~s}, 298) \rightarrow \mathrm{TiO}_{2}(\operatorname{soln}, 975)$ & $\Delta \mathrm{H}_{3}$ \\
\hline $\mathrm{Ti}(\mathrm{s}, 298)+\mathrm{O}_{2}(\mathrm{~g}, 298) \rightarrow \mathrm{TiO}_{2}(\mathrm{~s}, 298)$ & $\Delta \mathrm{H}_{4}$ \\
\hline $\mathrm{LaTiO}_{3.5} \mathrm{~N}_{\mathbf{x}}(\mathrm{s}, 298) \rightarrow 1 / 2 \mathrm{La}_{2} \mathrm{O}_{3}(\operatorname{soln}, 975)+\mathrm{TiO}_{2}(\operatorname{soln}, 975)+\mathbf{x} / 2 \mathrm{~N}_{2}(\mathrm{~g}, 975)$ & $\Delta \mathrm{H}_{\mathrm{ds}}$ \\
\hline $\mathrm{La}(\mathrm{s}, 298)+\mathrm{Ti}(\mathrm{s}, 298)+7 / 4 \mathrm{O}_{2}(\mathrm{~g}, 298)+\mathbf{x} / 2 \mathrm{~N}_{2}(\mathrm{~g}, 298) \rightarrow \mathrm{LaTiO}_{3.5} \mathrm{~N}_{\mathbf{x}}(\mathrm{s}, 298)$ & $\Delta \mathrm{H}_{\mathrm{f}}^{\circ}$ \\
\hline $\mathrm{N}_{2}(\mathrm{~g}, 298) \rightarrow \mathrm{N}_{2}(\mathrm{~g}, 975)$ & $\Delta \mathrm{H}_{7}$ \\
\hline$\Delta \mathrm{H}^{\circ}{ }_{\mathrm{f}}\left(\mathrm{LaTiO}_{3.5} \mathrm{~N}_{\mathbf{x}}\right)=\Delta \mathrm{H}_{\mathrm{f}}^{\circ}=-\Delta \mathrm{H}_{\mathrm{ds}}+1 / 2\left(\Delta \mathrm{H}_{1}+\Delta \mathrm{H}_{2}\right)+\left(\Delta \mathrm{H}_{3}+\Delta \mathrm{H}_{4}\right)+\mathbf{x} / 2 \Delta \mathrm{H}_{7}$ & \\
\hline
\end{tabular}


Table 10. Thermochemical cycle for calculation of the enthalpy of formation of $\mathrm{La}_{0.7} \mathrm{Ba}_{0.3} \mathrm{TiO}_{3.35} \mathrm{~N}_{\mathbf{x}}$.

\begin{tabular}{|c|c|}
\hline Reaction & $\Delta \mathrm{H}$ \\
\hline $\mathrm{La}_{2} \mathrm{Ti}_{2} \mathrm{O}_{7}(\mathrm{~s}, 298) \rightarrow \mathrm{La}_{2} \mathrm{Ti}_{2} \mathrm{O}_{7}($ soln, 975$)$ & $\Delta \mathrm{H}_{5}$ \\
\hline $2 \mathrm{La}(\mathrm{s}, 298)+2 \mathrm{Ti}(\mathrm{s}, 298)+7 / 2 \mathrm{O}_{2}(\mathrm{~g}, 298) \rightarrow \mathrm{La}_{2} \mathrm{Ti}_{2} \mathrm{O}_{7}(\mathrm{~s}, 298)$ & $\Delta \mathrm{H}_{6}$ \\
\hline $\mathrm{N}_{2}(\mathrm{~g}, 298) \rightarrow \mathrm{N}_{2}(\mathrm{~g}, 975)$ & $\Delta \mathrm{H}_{7}$ \\
\hline $\mathrm{O}_{2}(\mathrm{~g}, 298) \rightarrow \mathrm{O}_{2}(\mathrm{~g}, 975)$ & $\Delta \mathrm{H}_{8}$ \\
\hline $\mathrm{BaTiO}_{3}(\mathrm{~s}, 298) \rightarrow \mathrm{BaTiO}_{3}($ soln, 975) & $\Delta \mathrm{H}_{9}$ \\
\hline $\mathrm{Ba}(\mathrm{s}, 298)+\mathrm{Ti}(\mathrm{s}, 298)+3 / 2 \mathrm{O}_{2}(\mathrm{~g}, 298) \rightarrow \mathrm{BaTiO}_{3}(\mathrm{~s}, 298)$ & $\Delta \mathrm{H}_{10}$ \\
\hline $\begin{array}{l}\mathrm{La}_{0.7} \mathrm{Ba}_{0.3} \mathrm{TiO}_{3.35} \mathrm{~N}_{\mathbf{x}}(\mathrm{s}, 298) \rightarrow 0.35 \mathrm{La}_{2} \mathrm{Ti}_{2} \mathrm{O}_{7}\left(\text { soln, 975) }+0.3 \mathrm{BaTiO}_{3}(\operatorname{soln}, 975)+\right. \\
\mathbf{x} / 2 \mathrm{~N}_{2}(\mathrm{~g}, 975)\end{array}$ & $\Delta \mathrm{H}_{\mathrm{ds}}$ \\
\hline $\begin{array}{l}0.7 \mathrm{La}(\mathrm{s}, 298)+0.3 \mathrm{Ba}(\mathrm{s}, 298)+\mathrm{Ti}(\mathrm{s}, 298)+1.675 \mathrm{O}_{2}(\mathrm{~g}, 298)+\mathbf{x} / 2 \mathrm{~N}_{2}(\mathrm{~g}, 298) \\
\rightarrow \mathrm{La}_{0.7} \mathrm{Ba}_{0.3} \mathrm{TiO}_{3.35} \mathrm{~N}_{\mathbf{x}}(\mathrm{s}, 298)\end{array}$ & $\Delta \mathrm{H}_{\mathrm{f}}^{\circ}$ \\
\hline $\begin{array}{l}\Delta \mathrm{H}_{\mathrm{f}}^{\circ}\left(\mathrm{La}_{0.7} \mathrm{Ba}_{0.3} \mathrm{TiO}_{3.35} \mathrm{~N}_{\mathbf{x}}\right)=\Delta \mathrm{H}_{\mathrm{f}}^{\circ}=-\Delta \mathrm{H}_{\mathrm{ds}}+0.35\left(\Delta \mathrm{H}_{5}+\Delta \mathrm{H}_{6}\right)+0.3\left(\Delta \mathrm{H}_{9}+\right. \\
\left.\Delta \mathrm{H}_{10}\right)+\mathbf{x} / 2 \Delta \mathrm{H}_{7}\end{array}$ & \\
\hline
\end{tabular}

